Psychology. Journal of the Higher School of Economics.

2021. Vol. 18. N 3. P. 468-474. DOI: 10.17323/1813-8918-2021-3-468-474

\title{
PERSONALITY AND THE IMPACT OF CELEBRITY ENDORSEMENTS ON INSTAGRAM
}

\author{
Y. AMICHAI-HAMBURGER ${ }^{\mathrm{a}}$, S. ETGAR ${ }^{\mathrm{b}}$, H. GIL-AD $^{\mathrm{c}}$, \\ M. LEVITAN-GIAT ${ }^{\mathrm{d}}$, G. RAZ
}

\author{
a Sammy Ofer School of Communication, Interdisciplinary Center, Herzliya, 46150, Israel

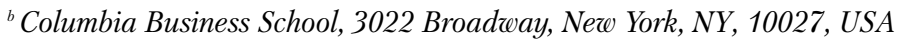 \\ ${ }^{c}$ YNET, 1 Noch Moses Str., Rishon Letzion, 7565236, Israel \\ ${ }^{d}$ Salesforce Israel, 114 Yigal Alon, Tel-Aviv, 6744320, Israel \\ ${ }^{e}$ Big Group, 3 Kalman Magen, Tel-Aviv, 6107075, Israel
}

\begin{abstract}
Celebrities are famous people who often belong to entertainment industry. They are known to have a strong influence on people's behavior. In the digital age this impact has expanded to include the online arena. Celebrities increasingly utilize Instagram, an online social network, to promote commercial products. It is important to learn to what extent people are influenced by this type of promotion and what sort of people are likely to be swayed by it. Research has demonstrated that people's personalities have a strong impact on their behaviors online. However, until now, these investigations have not included the relationship between personality and the degree of celebrity influence through social networks. This study examines how much the personality of a user is related to the degree to which he or she is influenced by these Celebrity Instagram messages. Participants comprised 121 students (34 males, 87 females). They answered questionnaires which focused on their personality and were asked about the degree of influence celebrities exerted upon them through Instagram. Results showed that people who are characterized as being open and having an internal locus of control are more resistant to such celebrity influences. This paper demonstrates that the personality of a recipient is likely to influence the degree of impact that a celebrity endorsement is likely to produce. The implications of these results are discussed.
\end{abstract}

Keywords: celebrity endorsements, Instagram, personality, locus of control, openness to experience, extroversion.

In the past, celebrities mainly publicized themselves by prominently displayed posters on bill boards. Today, online social networks ensure that celebrity culture is ubiquitous (Abidin, 2018). More recently, celebrities have been employed by companies to endorse certain products online. Until now, there has been no research as to which personality types are likely to be influenced by such online celebrity endorsements and, conversely, which personality types are likely to be resistant to such messages. There is a solid body of research demonstrating that people's personalities have a strong impact on their behaviors in social networks (Hamburger \& Ben-Artzi, 2000; Amichai-Hamburger \& Etgar, 2018). It therefore 
follows that personality will impact the degree of influence exerted by online celebrity endorsements.

In 2002, Amichai-Hamburger addressed the issue of web design when he invited designers to take into account the personality of a person who will use the site they are creating. He made this judgement following pivotal research showing that people with introverted personalities, who tend to have fewer social interactions and connections offline, have been shown to use the social channels available online as compensatory components in their lives (Hamburger \& Ben-Artzi, 2000). AmichaiHamburger went on to expand this idea, when he suggested that in fact extroversion and neuroticism were only two of the many personality theories that were likely to impact the use of the Internet and people's wellbeing. Amichai-Hamburger's idea, originally formulated in the 2002 article, prompted a snowball effect, and today more than one million academic articles pertaining to personality and the Internet are listed by Google Scholar. In fact, user behavior on Internet sites is now better understood because of the studies on the interaction between the user's personality and their behavior online. Personality traits found relevant to user behavior include: need for closure (Amichai-Hamburger et al., 2004); need for cognition (e.g. AmichaiHamburger et al., 2007); and the Big-Five (e.g. Amichai-Hamburger et al., 2002).

Moreover, personality has also been shown to explain people's behavior in different online contexts (Amichai-Hamburger, 2007; Amichai-Hamburger \& Hayat, 2013). Two personality characteristics that demonstrate flexibility are openness and extroversion (DeYoung et al., 2002). Openness refers to an open-minded, creative person, while extroversion refers to a friendly person who actively seeks company. Openness and extroversion were found to be negative predictors for conformity (DeYoung et al., 2002). This leads us to hypothesize that people who are high on extroversion and openness will be less influenced by celebrities on Instagram.

Another relevant personality theory is locus of control. This refers to the degree of influence people feel they have over their lives. It was found that while people with an internal locus of control tend to reject conformity, people with an external locus of control tend to conform (Biondo \& MacDonald, 1971). We predicted that people with an internal locus of control will be less influenced by celebrities on Instagram as compared to people with an external locus of control.

\section{Method}

\section{The Sample}

Participants included 121 people (34 males, 87 females), with an average age of 26 years, all of whom were students in a master's degree program in Social Studies. All subjects possessed an active Instagram account.

\section{Measurements}

Openness and Extroversion. Participants were given the Mini-IPIP to measure openness and extroversion. This was a 20 -item short form of the original Big 
Five Inventory (Costa $\&$ McCrae, 1992). Cronbach's Alpha $=.66$ was used for the openness questions and Cronbach's Alpha $=.64$ for the extroversion questions.

Locus of Control. The locus of control questionnaire was that of Nowicki \& Duke, 1974 based on the original Rotter's Locus of Control Scale (1966). Cronbach's Alpha $=.76$ internal consistency was used for the questionnaire.

Celebrity Influence. Participants completed a questionnaire focusing on the influence of celebrities on their purchasing decisions. This was a short questionnaire created by the authors to determine the scope of the impact that celebrities have on Instagram. Questions were as follows:

(a) What is the level of influence of a celebrity on Instagram on your decision to purchase a basic product such as a shirt?

(b) What is the level of influence of a celebrity on Instagram on your decision to purchase an expensive product such as a smartphone?

(c) What is the level of influence of a celebrity on Instagram on your decision to purchase a leisure item such as a vacation in Paris?

For each question, subjects located their answers on a scale ranging from 1 (not at all) to 5 (strong influence). We found internal consistency of Cronbach's Alpha $=.89$ between these three questions, therefore, we treated them as one variable by using these questions' average.

The questionnaires which were originally written in English, were translated into Hebrew, using the double translation method.

\section{Results}

Neither gender $(r=.12, p=.18)$ nor age $(r=.14, p=.12)$ were related to celebrity influence on purchase decisions.

Means, standard deviations, and intercorrelations that demonstrate the relationships among the independent and dependent variables can be found in Table 1 .

Table 1 indicates that locus of control is in a positive correlation with celebrity influence, while extroversion and openness to experience are not correlated to celebrity influence. To explore the relationship between the independent variables and celebrity influence while controlling for the covariances between independent variables, a stepwise multiple linear regression was conducted, with age and gender at the first step, and locus of control, extroversion and openness to experience at the second step. As can be seen in Table 2 , both locus of control $(\beta=.34, p<.001$,

Table 1

Means, Standard Deviations, and Correlation Matrix for All Variables

\begin{tabular}{|l|c|c|c|c|c|}
\hline & $\mathrm{M}$ & $\mathrm{SD}$ & 1 & 2 & 3 \\
\hline Celebrity influence & 2.11 & 1.09 & & & \\
\hline Openness to experience & 3.85 & 0.63 & -.144 & & \\
\hline Extroversion & 3.34 & 0.71 & .100 & .101 & \\
\hline Locus of control & 19.50 & 4.99 & $.312^{* *}$ & .166 & .121 \\
\hline
\end{tabular}

$* * p<.001, \mathrm{~N}=121$. 
Table 2

Unstandardized and Standardized Coefficients, Significant and Multicollinearity Tests for the Multiple Regression Analysis

\begin{tabular}{|c|l|c|c|c|c|c|}
\hline & & $\mathbf{B}$ & $\mathbf{S E}$ & $\beta$ & $\mathbf{t}$ & $\mathbf{V I F}$ \\
\hline \multirow{3}{*}{ Step I } & Age & .05 & .03 & .14 & 1.507 & 1.00 \\
\cline { 2 - 7 } & Gender & .27 & .22 & .11 & 1.245 & 1.00 \\
\hline \multirow{3}{*}{ Step II } & Age & .04 & .03 & .13 & 1.526 & 1.01 \\
\cline { 2 - 7 } & Gender & .28 & .21 & .11 & 1.333 & 1.01 \\
\cline { 2 - 7 } & Locus of control & .07 & .02 & .34 & $3.89^{* *}$ & 1.05 \\
\cline { 2 - 7 } & Openness to change & -.35 & .15 & -.20 & $-2.35^{*}$ & 1.05 \\
\cline { 2 - 7 } & Extroversion & .12 & .13 & .08 & 0.89 & 1.03 \\
\hline
\end{tabular}

DV: Celebrity Influence; ${ }^{*} \mathrm{p}<.05,{ }^{* *} \mathrm{p}<.001$.

$\mathrm{VIF}=1.05)$ and openness to experience $(\beta=-.20, p=.02, \mathrm{VIF}=1.05)$ were significantly correlated with celebrity influence, while the other variables were not found to have such an effect.

\section{Discussion}

In accordance with our hypothesis, we found that open people and those with an internal locus of control are significantly less likely to be influenced by celebrities on Instagram. It seems that they exercise more control on their lives and therefore are less influenced by external forces such as celebrities.

When it comes to extroverts, our hypothesis was not confirmed. Extroverts were not less likely to be influenced by celebrities than introverts. One possible explanation may be the fact that extroverts are more active on social networks (Dhar \& Jha, 2014), and this might reduce the impact of their general tendency to be more resistant to conformity.

In future studies we suggest that the effect of celebrities on extroverts be studied more carefully. Such future studies should initially assess the amount of use participants make of social networks. This will allow for a broader analysis of our explanation as to why the extroverts in our study did not show greater resistance to the influence of celebrities. Our study confirms the importance of studying personality in the context of online behavior.

This study examined the influence of celebs on the public through Instagram. Instagram was chosen because it is widely used by celebrities for this purpose. As Reilly (2021) points out, Tik Tok is being increasingly used by celebs as a vehicle for impacting their public. Many celebs who made their reputations outside social networks, are today active on Tik Tok along with celebs who actually established themselves on Tik Tok. With this in mind, it is reasonable to expect that the type of celeb Instagram behavior assessed in this study is likely to become popular on 
Tik Tok as well. It is recommended that future studies focus further on the interaction between user's personality and persuasion by celebrities online.

\section{References}

Abidin, C. (2018). Internet celebrity: Understanding fame online. Bingley, UK: Emerald Publishing. Amichai-Hamburger, Y. (2002). Internet and personality. Computers in Human Behavior, 18(1), 1-10. Amichai-Hamburger, Y. (2007). Personality, individual differences and Internet use. In A. Joinson, K. McKenna, T. Postmes, \& U.-D. Reips (Eds.), The Oxford handbook of Internet psychology (pp. 187-204). Oxford, UK: Oxford University Press.

Amichai-Hamburger, Y., \& Etgar, S. (2018). Personality and Internet use: The case of introversion and extroversion. In A. Attrill-Smith, C. Fullwood, D. Kuss, \& M. Keep (Eds.), Oxford handbook of Internet psychology. New York, NY: Oxford University Press.

Amichai-Hamburger, Y., Fine, A., \& Goldstein, A. (2004). The impact of Internet interactivity and need for closure on consumer preference. Computers in Human Behavior, 20(1), 103-117.

Amichai-Hamburger, Y., \& Hayat, Z. (2013). Internet and personality. In Y. Amichai-Hamburger (Ed.), The social net: Understanding our online behavior (pp. 1-20). Oxford University Press.

Amichai-Hamburger, Y., Kaynar, O., \& Fine, A. (2007). The effects of need for cognition on Internet use. Computers in Human Behavior, 23(1), 880-891.

Amichai-Hamburger, Y., Wainapel, G., \& Fox, S. (2002). "On the Internet no one knows I'm an introvert”: Extroversion, neuroticism, and Internet interaction. Cyberpsychology, Behavior, and Social Networking, 5(2), 125-128.

Biondo, J., \& MacDonald, A. P., Jr. (1971). Internal-external locus of control and response to influence attempts. Journal of Personality, 39, 407-419.

Costa, P. T., \& McCrae, R. R. (1992). Revised NEO Personality Inventory (NEO-PI-R) and NEO FiveFactor Inventory (NEO-FFI) manual. Odessa, FL: Psychological Assessment Resources.

DeYoung, C. G., Peterson, J. B., \& Higgins, D. M. (2002). Higher-order factors of the Big Five predict conformity: Are there neuroses of health? Personality and Individual Differences, 33, 533-552.

Dhar, J., \& Jha, A. K. (2014). Analyzing social media engagement and its effect on online product purchase decision behavior. Journal of Human Behavior in the Social Environment, 24, 791-798.

Hamburger, A. Y., \& Ben-Artzi, E. (2000). The relationship between extraversion and neuroticism and the different uses of the Internet. Computers in Human Behavior, 16, 441-449.

Reilly, L. (2021, June 9). TikTok's Summer-defining “Coconut Girl” trend is just \$15 at target. InStyle. https://www.instyle.com/fashion/tiktok-coconut-girl-trend-floral-swimsuit-celebrity

Rotter, J. B. (1966). Generalized expectancies for internal versus external control of reinforcement. Psychological Monographs: General and Applied, 80, 1-28.

Yair Amichai-Hamburger - Director, The Research Center for Internet Psychology, Sammy Ofer School of Communication, Interdisciplinary Center (IDC), Professor.

Research Area: Internet and wellbeing.

E-mail: yairah@idc.ac.il

Shir Etgar - Visiting scholar, Columbia Business School, DSc.

Research Area: the ways new technologies and new media affect individuals' social and cognitive processes.

E-mail: shir.etgar@gmail.com 
Hadar Gil-Ad - Journalist, YNET, M.A. in Communication \& New Media.

Research Area: the interaction between online platforms and content and how it affects the online user.

E-mail: hadargg28@gmail.com

Michal Levitan-Giat - Strategic Account Executive, Salesforce Israel, M.A. in Communication $\&$ New Media.

Research Area: the influence of social media on the business world.

E-mail: michallv@hotmail.com

Gaya Raz - VP Sarona Market, Big Group, M.A. in Communication \& New Media.

Research Area: online romantic relationships.

E-mail: gaya124@walla.co.il

\title{
Личность и влияние рекламы с участием знаменитостей в Instagram
}

\author{
Я. Амихай-Хамбургер ${ }^{\mathrm{a}}$, Ш. Этгар ${ }^{\mathrm{b}}$, Х. Гиль-Ад \\ ${ }^{a}$ Sammy Ofer School of Communication, Interdisciplinary Center, Herzliya, 46150, Израиль \\ ${ }^{b}$ Columbia Business School, 3022 Broadway, New York, NY, 10027, CШA \\ ' YNET, 1 Noch Moses Str., Rishon Letzion, 7565236, Израиль \\ ${ }^{d}$ Salesforce Israel, 114 Yigal Alon, Tel-Aviv, 6744320, Израиль

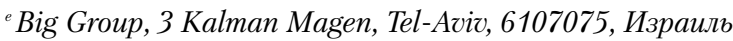

\section{Резюме}

Знаменитости - это известные люди, которые нередко принадлежат к индустрии развлечений. Известно, что они оказывают значительное влияние на поведение людей. В эпоху цифровых технологий это влияние распространилось и на онлайн-арену. Знаменитости все чаще используют социальную сеть Instagram для продвижения коммерческих продуктов. Важно исследовать, в какой степени люди подвержены влиянию такого типа продвижения и на каких людей он способен влиять. Исследования показали, что на поведение в Интернете в значительной мере влияет личность человека. Однако до сих пор подобные исследования не включали взаимосвязь между личностью и степенью влияния знаменитостей посредством социальных сетей. В этом исследовании изучается вопрос о том, насколько личность пользователя связана со степенью влияния на него сообщений знаменитостей в Instagram. В исследовании принял участие 121 студент (34 юноши, 87 девушек). Они отвечали на опросники, посвященные их личностным особенностям. Испытуемых также спрашивали о степени влияния, которое знаменитости оказывают на них через Instagram. Результаты показали, что люди, которых можно охарактеризовать как открытых и обладающих внутренним локусом контроля, более устойчивы к такому влиянию со стороны знаменитостей. В настоящей работе показано, что личность получателя информации, вероятно, влияет на степень воздействия одобрительных высказываний знаменитостей. Обсуждаются выводы на основе этих результатов.

Ключевые слова: одобрительные высказывания знаменитостей, Instagram, личность, локус контроля, открытость опыту, экстраверсия. 
Яир Амихай-Хамбургер - директор, The Research Center for Internet Psychology Sammy Ofer School of Communication, Interdisciplinary Center (IDC), професcop. Сфера научных интересов: Интернет и благополучие человека.

Контакты: yairah@idc.ac.il

Шир Этгар - приглашенный научный сотрудник, Columbia Business School, доктор социальной психологии.

Сфера научных интересов: способы влияния новых технологий и новых медиа на социальные и когнитивные процессы человека.

Контакты: shir.etgar@gmail.com

Хадар Гиль-Ад - журналист, YNET, магистр в области коммуникаций и новых медиа.

Сфера научных интересов: взаимодействие между онлайн-платформами и контентом и его влияние на онлайн-пользователя.

Контакты: hadargg28@gmail.com

Михаль Левитан-Гиат - директор по работе со стратегическими клиентами, Salesforce Israel, магистр в области коммуникаций и новых медиа.

Сфера научных интересов: влияние социальных сетей на мир бизнеса.

Контакты: michallv@hotmail.com

Гая Раз - вице-президент, Sarona Market, Big Group, магистр в области коммуникаций и новых медиа.

Сфера научных интересов: романтические отношения онлайн.

Контакты: gaya124@walla.co.il 